\title{
EFFECT OF GOAT BREEDS, SEMEN DILUENTS AND FREEZING METHODS ON SPERM FREEZABILITY AND REPRODUCTIVE PERFORMANCE
}

\author{
K.M. MOHAMMED ${ }^{*}$, M.H. KHALIL ${ }^{* *}$ and A.M. AL-SAEF ${ }^{* * *}$ \\ *Animal Reproduction Research Institute (ARRI), AI \& ET Dept, Giza, AL-Haram, Egypt. \\ ${ }^{* *}$ Faculty of Agriculture, Benha University, Moshtohor, zip code 13736 Kalyoubia, Egypt \\ *** College of Agriculture \& Veterinary Medicine, Qassim University, Saudi Arabia \\ Correspondence email: kamel14@hotmail.com
}

Received at: 29/3/2012

Accepted: 6/5/2012

\section{ABSTRACT}

Two experiments were designed to study the effect of semen extenders and freezing regimens on post-thaw semen motility and viability index, effect of bucks breed was also included (experiment 1). In experiment 2, semen diluents effects on reproductive performance was conducted. Semen was collected from bucks breeds (Aradi (A), Damascuss (D) and cross $\left(1 / 2 \mathrm{~A}^{1} / 2 \mathrm{D}\right)$. Good quality semen was divided into 4 portions, each diluted with one diluent (Milk, Na.Citrate, Tris and Na.Bicarbonate). The diluted semen was packaged into $0.5 \mathrm{ml}$ straws then cooled to $5^{\circ} \mathrm{C}$. After equilibration, half of the packaged straws were suspended $15 \mathrm{~cm}$ above liquid nitrogen (LN) for $15 \mathrm{~min}$ (Freezing regimen1; slow). Other half of straws was suspended at height 15 and $5 \mathrm{~cm}$ of $\mathrm{LN}$ for 10 and $5 \mathrm{~min}$, respectively (Freezing regimen2; rapid) before plunged into LN. Frozen semen was thawed for post-thaw motility and viability. In the second experiment, semen with good quality was extended with three types of extenders (Milk, Na.Citrate and Tris). Diluted semen were cooled to $5^{\circ} \mathrm{C}$ and used for AI. Results revealed that, pre-freeze semen motility was significant higher in Tris, Na.Citrate and Na.Bicarbonate than milk diluent. Post-thaw semen motility and viability were highly significant for milk and $\mathrm{Na}$.Citrate than Tris and Na.Bicarbonate diluents. Post-thaw semen motility was significantly higher in Aradi and Damascus than cross breed. Post-thaw semen motility and viability revealed, significant higher means for Freezing regimen 2 than regimen 1 . Milk was significantly higher than Tris and Na.Citrate diluents for fertility and fecundity. It was concluded that, regarding to post-thaw semen viability, fertility $\%$, kidding $\%$, fecundity $\%$ and prolificacy $\%$, milk is preferable than Tris and Na.citrate diluents. 


\section{تأثير سلالة الماعز ونوع المخفات وكذلك نظم التجميا على كفاءة السائل المنوى للتجميا وتأثير ذلك التك

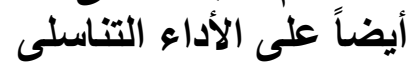

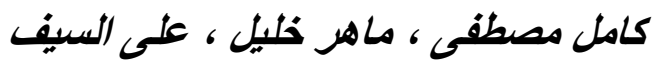

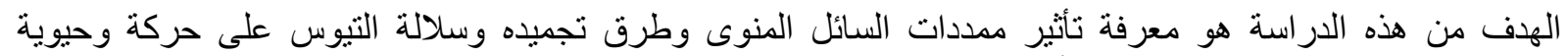

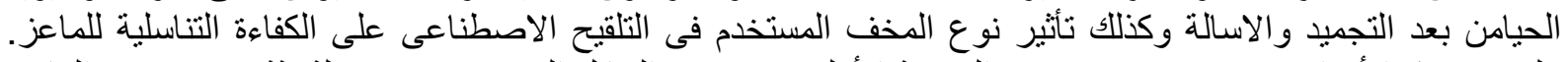

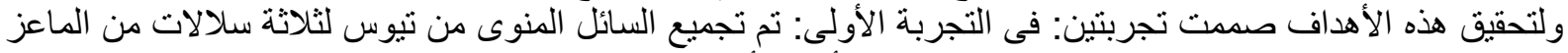

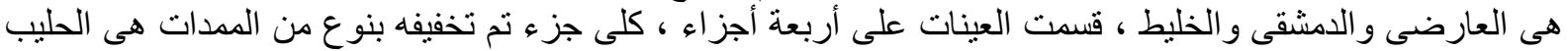

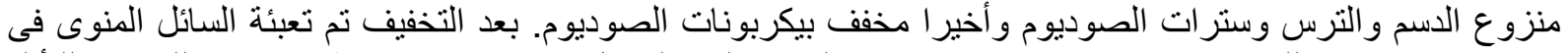

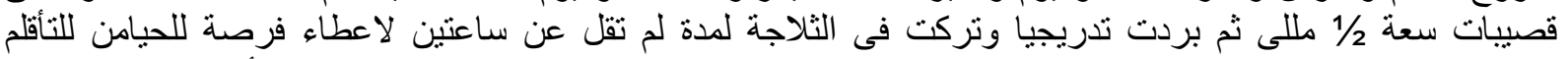

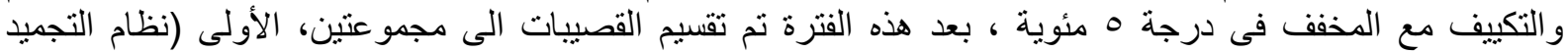

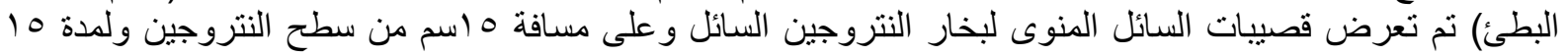

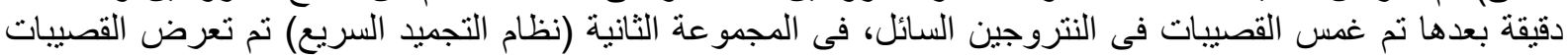

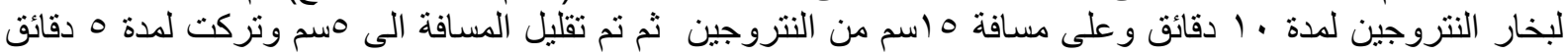

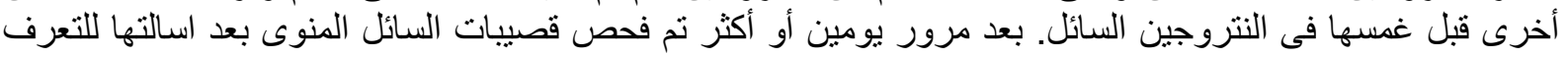

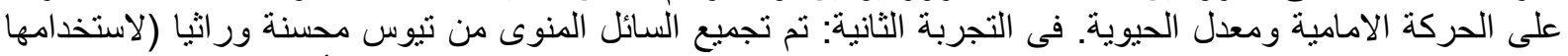

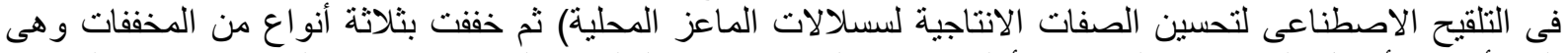

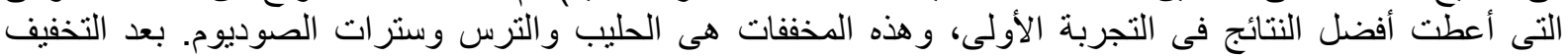

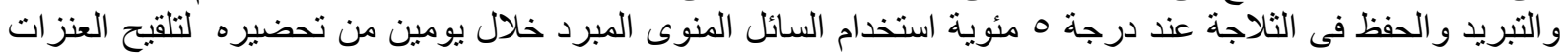

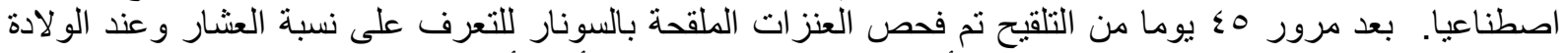

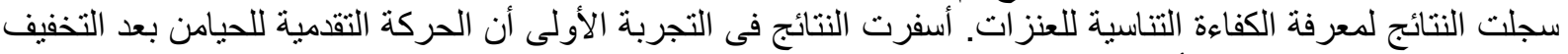

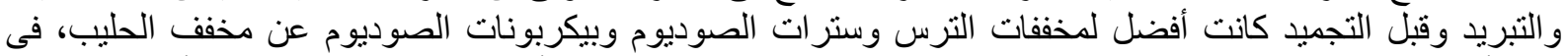

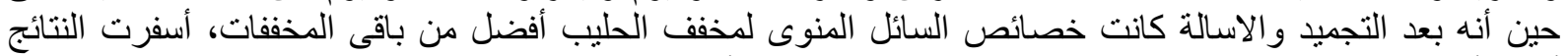

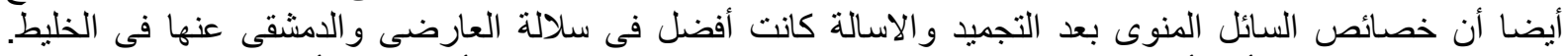

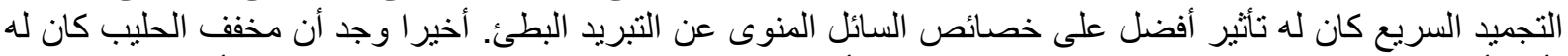

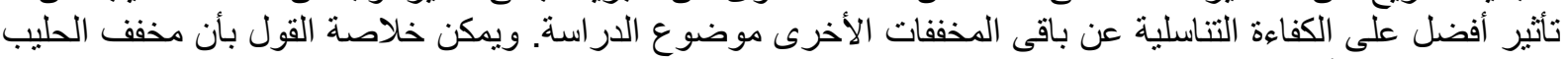

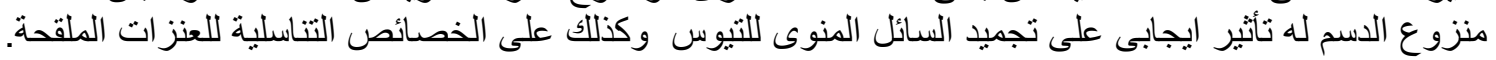

Key words: Buck, semen diluents, artificial insemination, fertility.

\section{INTRODUCTION}

The success of artificial insemination (AI) is based on the ability to efficiently collect and cryopreserve spermatozoa from quality bucks for use on does over generations (Amoah and Gelaye, 1990). Three methods of semen preservation (fresh, refrigerated and frozen) are used worldwide in goats (Evans and Maxwell, 1987; Leboeuf et al., 2000). The use of refrigerated semen is a common strategy in circumstances where a particular male is shared by a group of farmers located within a relatively small area. Spermatozoa are likely to suffer a considerable damage and deterioration during dilution and preservation at low temperature; therefore, suitable diluents are a basic necessity for successful preservation of spermatozoa and higher conception rate in field trials using diluted semen (Salamon and Maxwell, 1995). The principal problem in the world wide development of AI in goats is related to the use of frozen semen, since the freezing process reduces the viability of sperm cells (Ritar, 1993). Tris diluent was found to maintain higher quality of semen pre-freeze and post-thaw (Drobnis et al., 1980; Deka and Rao, 1987; Chauhan and Anand, 1990; Sinha et al., 1991; Tuli and Holtz, 1992). Also, Singh and Purbey (1996) concluded that the Tris diluter was superior for freezing goat semen than citrate diluter concerning post-thaw motility. Contrary, Salvador et al. (2007) cited that, milk diluent provided higher viability of spermatozoa than semen diluted in Tris and citrate. Moreover, Drobnis et al. (1980) recorded 
higher extracellular of aspartate aminotransferase (AST) activity released in Tris diluent than skim milk after thawing goat semen. However, Memon et al. (1985) and Mukhrejee and Nelson (1987) could not find significant difference between Tris and skim milk extenders for freezing buck semen. The present study aimed to investigate the effect of semen extenders, freezing regimens and bucks breed on postthaw semen motility and viability index, as well as investigate if semen diluents influenced reproductive performance of goats in arid environment.

\section{MATERIALS and METHODS}

\section{Animals and management:}

A crossbreeding program between Saudi goats (Aradi, A) as a native breed with Syrian goats (Damascus, D) was carried out at Camel and Range Research Center (AlJouf province, Northern region of Saudi Arabia located at latitude of $29.97^{\circ}$ north and longitude of $40.21^{\circ}$ Wand at 684 meters above sea level) to improve the productivity of Aradi local goats for meat and milk production through crossbreeding and selection. Genetically selected and improved bucks were used to disperse these valuable genes throughout the goat herds in Saudi Arabia. Animals were housed in semishaded/open front barn and fed on a commercial concentrate and alfalfa hay. The amount of concentrate and hay were calculated according to the nutritional requirements for goats (National Research Council; NRC, 1981) which dependent on animal ages and production status. Water, straw, salt and minerals supplemented in blocks were freely available to all animals.

\section{Experiment 1:}

\section{Semen preparation and freezing process:}

Four semen extenders and two freezing programs were evaluated for freezing buck goat semen. Constituents of these diluents are shown in Table 1. Three to four ejaculates per buck were collected using artificial vagina. Semen samples with motility $\geq 70 \%$ were used for processing. Semen samples for each buck were divided into 4 portions, each portion was added to one diluent (dilution rate 1:15-20; according to semen concentration). The diluted semen samples were packaged into $0.5 \mathrm{ml}$ straws at room temperature and arranged horizontally on freezing racks then gradually cooled to 5 ${ }^{\circ} \mathrm{C}$ within 1-2 hrs. and placed in a refrigerator for equilibration. After equilibration time, half of the total packaged straws were suspended in liquid nitrogen (LN) vapor inside an foam box container at height $15 \mathrm{~cm}$ above $\mathrm{LN}$, for $15 \mathrm{~min}$ (Freezing regimen 1; slow). Other half of straws were suspended in LN vapor at height 15 and $5 \mathrm{~cm}$ of $\mathrm{LN}$, for 10 and $5 \mathrm{~min}$ (Freezing regimen 2; rapid) before plunged into LN. Frozen semen straws were stored in LN for 24-72 hrs before thawing. The frozen semen was thawed in a water bath at $37{ }^{\circ} \mathrm{C}$ for 2-3 minutes. Pre-freeze semen motility was recorded using microscope fitted with a biotherm stage $\left(37^{\circ} \mathrm{C}\right)$, as well as, the postthaw motility at $0 \mathrm{hr}$ after thawing and reassessed after 1, 2 and 3 hours of thermal stress and the viability index (sum of semen motility $/ 2$ at $0 \mathrm{hr}$. + semen motility at 1 and $2 \mathrm{hr}$. + semen motility $/ 2$ at $3 \mathrm{hr}$.) according to Milovanov (1962) was determined for each semen sample. Twenty two bucks from three breeds (Aradi, Damascus and Cross $1 / 2$ Ardi $x 1 / 2$ Damascus) were used in the study. The effect of semen extenders, freezing regimens and of bucks breed on post-thaw semen motility and viability index were conducted in this experiment.

\section{Experiment 2:}

\section{Semen preparation:}

Semen samples were collected from genetically selected and improved bucks (to disperse these valuable genes throughout the local goat herds in Saudi Arabia) with good quality were extended with extenders using dilution rate of $1: 15$ to $1: 20$ (semen: diluent) according to sperm concentration. Three types of extenders; skim milk, Na. citrate and Tris were used as based extenders for semen dilution, constituents of the diluents are presented in Table 1. The diluted semen samples were gradually cooled within $2 \mathrm{hrs}$ to $5^{\circ} \mathrm{C}$ and stored in a refrigerator as chilled semen to be used for artificial insemination (Azawi et al., 1993). 
Estrous synchronization and artificial insemination (AI):

Intravaginal progestagen release device (CIDR) containing $300 \mathrm{mg}$ progesterone or intravaginal progesterone impregnated sponges containing 30 or $45 \mathrm{mg}$ fluorogesteone acetate (FGA) were administered to 930 does of local different breeds (native and cross breeds of unknown origin), and maintained in situ for 15-17 days. At the day of sponge withdrawal 200$300 \mathrm{IU} / \mathrm{eCG}$ was injected intramuscular. AI was done blindly (irrespective to signs of estrus) 48-60 hours after sponge removal, using chilled diluted semen $(0.5 \mathrm{ml}$ containing 120-150 $\times 10^{6}$ motile spermatozoa). AI was carried out using insemination pipette and vaginal speculum. The hind legs of the doe was lifted and placed at an angle of $45^{\circ}$ to the horizontal railing. The vaginal speculum was introduced into the vaginal passage and the cervix was located with the help of light and by gentle sideways or downward manipulation of the speculum. Semen was deposited up to a depth of $0.5-1.0 \mathrm{~cm}$ into the cervix (cervical insemination). Pregnancy diagnosis was applied 30-45 days post insemination with the aid of ultrasound scanner. Different breeds of Aradi (A), Damascus (D) and Cross $\left(1 / 2 \mathrm{~A}^{1} / 2 \mathrm{D}\right)$ goats were used. Irrespective to goat breeds, Pooled collected data from 2006 through 2010 were performed for statistical analysis to study the effect of semen diluents and mating seasons on the reproductive performance. Parameters of the reproductive performance which done in this study includes: Fertility rate (pregnant does/does inseminatedx100), Kidding rate (kidded does/pregnant does)x 100), Fecundity rate (kids born /pregnant does $\mathrm{x}$ 100), and Prolificacy rate (kids born /kidded doesx 100).

\section{Statistical analysis:}

All pooled data (collected from 2006 through 2011) of studied parameters affected postthaw semen motility and viability and artificial insemination parameters which affected the reproductive traits (fertility, kidding, fecundity, and prolificacy rates) were statistically analyzed using the general linear models (GLM) procedures of the analysis Systems with a subsequent Duncas test was used to compare the mean values resulting from the various treatments. All analyses were carried out using the SPSS 9 for Windows statistical software package.

\section{RESULTS}

As shown from Table 2, pre-freeze semen motility was significant higher $(\mathrm{P}<0.05)$ in Tris diluent (78.49 \pm 0.96$)$, sodium citrate (76.72 \pm 0.87$)$ and sodium-citrate-bicarbonate $(76.08 \pm 10.93)$ than milk diluent (71.88 \pm 1.29$)$. Post-thaw semen motility were highly significant $(\mathrm{P}<0.05)$ for milk $(46.44 \pm 1.33)$ and sodium citrate (42.95 \pm 0.87$)$ than Tris $(38.80 \pm 1.40)$ and Sodium-citrate-bicarbonate $\quad(35.81 \pm 1.45)$ diluents. However, the viability index of post-thaw semen motility were significant higher $(\mathrm{P}<0.05)$ for milk $(103.48 \pm 3.38)$, sodium citrate $(104.18 \pm 3.13)$ and Tris $(95.06 \pm 4.06)$ than sodium-citratebicarbonate $(91.50 \pm 4.23)$ diluents.

Irrespective to diluent types and freezing protocol, the mean values of pre-freezing semen motility for Aradi (A), Damascus (D) and Cross bucks breed $1 / 2 \mathrm{~A}^{1} / 2 \mathrm{D}$ were $75.57 \pm 0.73, \quad 75.91 \pm 0.84$ and $76.55 \pm 1.35$, respectively, with no significant differences (Table 3). The same trends, were observed for VI and its mean values were $101.38 \pm 2.47,95.49 \pm 3.68$ and $93.48 \pm 4.74$, for Aradi, Damascus and cross bucks breed, respectively, with no significant differences (Table 3). However, significant higher values $(\mathrm{P}<0.05)$ of post-thaw semen motility at $0 \mathrm{hr}$. were achieved by Aradi (42.27 \pm 0.91$)$ and Damascus (39.65 \pm 1.30$)$ than cross bucks breed $(38.11 \pm 1.71)$, irrespective to diluents and freezing regimens (Table 3). The overall means of motility for pre-freeze, post-thaw and viability index were $75.81 \pm 0.52$, $40.92 \pm 0.69$ and $98.56 \pm 1.89$, respectively, irrespective to semen diluents, bucks breeds and freezing regimens.

As presented in Table 4, the effect of freezing protocols on post-thaw semen motility and viability index revealed that highest mean percentages $(\mathrm{P}<0.001)$ of 
post-thaw motility were achieved in freezing regimen 2 at $0 \mathrm{hr}$. $(47.74 \pm 0.66 \quad v s$ $34.15 \pm 1.04), \quad 1 \quad$ hr. $\quad(42.74 \pm 0.71 \quad v s$ $28.54 \pm 1.00), \quad 2$ hrs. $\quad(38.59 \pm 0.72 \quad v s$ $22.60 \pm 0.93), \quad 3$ hrs. $\quad(31.65 \pm 0.88$ vs $16.12 \pm 0.84)$ and viability index (121.03 \pm 1.89 vs $76.28 \pm 2.59)$ than freezing regimen 2, irrespective to semen diluents and buck breeds. Analysis of variance (Table 5) showed, significant interactions $(\mathrm{P}<0.001)$ between diluents and bucks breeds on prefreeze sperm motility, post-thaw motility and VI. In the same line, the effect of interactions between freezing regimens and diluents were highly $(\mathrm{P}<0.001)$ significant on post-thaw semen motility and viability index. However, the interaction between bucks individuality and freezing regimens and/or semen diluents on post-thaw semen motility and VI were nonsignificant.
Regarding the effect of semen diluents used for $\mathrm{AI}$ on the reproductive performance; the fertility rate were $45.21 \%(33 / 73), 34.40 \%$ $(215 / 625)$ and $57.76 \%(134 / 232)$ for does that had been inseminated with Tris, sodium citrate and milk diluted semen, respectively (Table 6). The corresponding kidding\%, fecundity $\%$, and prolificacy $\%$ were $90.91 \%$, $143 \%, 157 \% ; 89.77 \%, 143 \%, 159 \%$; and $96.99 \%, 179 \%, 185 \%$, for Tris, sodium citrate and milk semen diluents, respectively, with overall means were $41.08 \%, 92.39 \%$, $156 \%$ and $168 \%$, for fertility, kidding, fecundity and prolificacy rates, respectively (Table 6). Statistical analysis revealed that, milk diluent was significantly higher $(\mathrm{P}<0.05)$ than Tris and sodium citrate diluents for fertility and fecundity rates. However, no significant effect between diluents on kidding and prolificacy rates.

Table 1: Composition of semen extenders (g/100 ml distilled water).

\begin{tabular}{lcccc}
\hline \multirow{2}{*}{ Constituents $(\mathrm{gm})$} & \multicolumn{5}{c}{ Diluents } \\
\cline { 2 - 5 } & 1 & 2 & 3 & 4 \\
\hline Skimmed milk Powder & 10 & $=$ & $=$ & $=$ \\
\hline Na. Citrate & $=$ & 2.9 & $=$ & 2.00 \\
\hline Tris & $=$ & $=$ & 3.786 & $=$ \\
\hline Citric acid monohydrate & $=$ & $=$ & 2.172 & $=$ \\
\hline Sodium Bicarbonate & $=$ & $=$ & $=$ & 0.21 \\
\hline KCl & $=$ & $=$ & $=$ & 0.04 \\
\hline Glucose & $=$ & $=$ & 0.625 & 0.30 \\
\hline Egg Yolk $(\mathrm{v} / \mathrm{v})$ & $15 \%$ & $15 \%$ & $15 \%$ & $15 \%$ \\
\hline Glycerol $(\mathrm{v} / \mathrm{v})$ & $7 \%$ & $7 \%$ & $7 \%$ & $7 \%$ \\
\hline Gentamycin $(\mu \mathrm{g})$ & 50.000 & 50.000 & 50.000 & 50.000 \\
\hline Tylosin $(\mu \mathrm{g})$ & 50.000 & 50.000 & 50.000 & 50.000 \\
\hline Lincospectin $(\mu \mathrm{g})$ & 15.000 & 15.000 & 15.000 & 15.000 \\
\hline
\end{tabular}

Table 2: Effect of semen extenders (diluents) on Pre-freezing and post-thaw semen motility and viability index $($ Mean \pm SE) 


\begin{tabular}{|c|c|c|c|c|c|c|}
\hline \multirow{2}{*}{$\begin{array}{c}\text { Semen } \\
\text { extenders }\end{array}$} & \multirow{2}{*}{$\begin{array}{c}\text { Pre-freezing } \\
\text { motility }\end{array}$} & \multicolumn{5}{|c|}{ Post-thaw semen motility ( $\%$ ) } \\
\hline & & $0 \mathrm{hr}$ & $1 \mathrm{hr}$ & $2 \mathrm{hrs}$ & $3 \mathrm{hrs}$ & $\begin{array}{l}\text { Viability } \\
\text { Index }\end{array}$ \\
\hline Milk (1) & $71.88 \pm 1.29^{b}$ & $46.44 \pm 1.33^{\mathrm{a}}$ & $39.36 \pm 1.29^{\mathrm{a}}$ & $31.08 \pm 1.27^{\mathrm{a}}$ & $19.64 \pm 1.18^{\mathrm{b}}$ & $103.48 \pm 3.38^{\mathrm{a}}$ \\
\hline Na. citrate (2) & $76.72 \pm 0.87^{\mathrm{a}}$ & $42.95 \pm 1.10^{\mathrm{a}}$ & $37.87 \pm 1.11^{\mathrm{a}}$ & $33.11 \pm 1.30^{\mathrm{a}}$ & $23.44 \pm 1.30^{\mathrm{ab}}$ & $104.18 \pm 3.13^{\mathrm{a}}$ \\
\hline Tris (3) & $78.49 \pm 0.96^{\mathrm{a}}$ & $38.80 \pm 1.40^{\mathrm{b}}$ & $34.57 \pm 1.46^{\mathrm{ab}}$ & $29.07 \pm 1.45^{\mathrm{a}}$ & $25.12 \pm 1.43^{\mathrm{a}}$ & $95.06 \pm 4.06^{\mathrm{ab}}$ \\
\hline $\begin{array}{c}\text { Na.- citrate- } \\
\text { bicarbonate (4) }\end{array}$ & $76.08 \pm 10.93^{\mathrm{a}}$ & $35.81 \pm 1.45^{\mathrm{b}}$ & $30.92 \pm 1.48^{b}$ & $29.15 \pm 1.43^{\mathrm{a}}$ & $27.04 \pm 1.55^{\mathrm{a}}$ & $91.50 \pm 4.23^{b}$ \\
\hline Total & $75.81 \pm 0.52$ & $40.92 \pm 0.69$ & $35.61 \pm 0.69$ & $30.56 \pm 0.69$ & $23.85 \pm 0.70$ & $98.56 \pm 1.89$ \\
\hline
\end{tabular}

Means in the same column with different superscripts are significantly differ at $\mathrm{P}<0.05$

Table 3: Effect of Buck breeds on Pre-freezing and post-thaw semen motility and viability index $($ Mean \pm SE).

\begin{tabular}{ccccccc}
\hline \multirow{2}{*}{ Bucks Breed } & Pre-freezing & \multicolumn{5}{c}{ Post-thaw semen motility (\%) } \\
\cline { 3 - 7 } & & $0 \mathrm{hr}$ & $1 \mathrm{hr}$ & $2 \mathrm{hrs}$ & $3 \mathrm{hrs}$ & $\begin{array}{c}\text { Viability } \\
\text { Index }\end{array}$ \\
\hline Ardi (A) & $75.57 \pm 0.73^{\mathrm{a}}$ & $42.27 \pm 0.91^{\mathrm{a}}$ & $36.87 \pm 0.89^{\mathrm{a}}$ & $31.31 \pm 0.92^{\mathrm{a}}$ & $21.13 \pm 0.94^{\mathrm{a}}$ & $101.38 \pm 2.47^{\mathrm{a}}$ \\
\hline Damascus (D) & $75.91 \pm 0.84^{\mathrm{a}}$ & $39.65 \pm 1.30^{\mathrm{ab}}$ & $34.27 \pm 1.36^{\mathrm{a}}$ & $29.58 \pm 1.30^{\mathrm{a}}$ & $23.64 \pm 1.31^{\mathrm{a}}$ & $95.49 \pm 3.68^{\mathrm{a}}$ \\
\hline $\begin{array}{c}\text { Cross breed } \\
(1 / 2 \mathrm{~A} 1 / 2 \mathrm{D})\end{array}$ & $76.55 \pm 1.35^{\mathrm{a}}$ & $38.11 \pm 1.71^{\mathrm{b}}$ & $33.31 \pm 1.77^{\mathrm{a}}$ & $29.53 \pm 1.73^{\mathrm{a}}$ & $23.18 \pm 1.71^{\mathrm{a}}$ & $93.48 \pm 4.74^{\mathrm{a}}$ \\
\hline Total & $75.81 \pm 0.52$ & $40.92 \pm 0.69$ & $35.61 \pm 0.69$ & $30.56 \pm 0.69$ & $23.85 \pm 0.70$ & $98.56 \pm 1.89$
\end{tabular}

Means in the same column with different superscripts are significantly differ at $\mathrm{P}<0.05$

Table 4: Effect of freezing regimens on post-thaw semen motility and viability index $(\mathrm{Mean} \pm \mathrm{SE})$.

\begin{tabular}{|c|c|c|c|}
\hline \multirow{2}{*}{ Post-thaw hours } & \multicolumn{3}{|c|}{ Post-thaw semen motility ( $\%)$} \\
\hline & $\begin{array}{c}\text { Regimen } 1 \\
\text { (Slow freezing) }\end{array}$ & $\begin{array}{c}\text { Regimen } 2 \\
\text { (Rapid freezing) }\end{array}$ & Overall \\
\hline $0 \mathrm{hr}$ & $34.15 \pm 1.04^{b}$ & $47.74 \pm 066^{\mathrm{a}}$ & $40.92 \pm 0.69$ \\
\hline $1 \mathrm{hr}$ & $28.54 \pm 1.00^{b}$ & $42.74 \pm 0.71^{\mathrm{a}}$ & $35.61 \pm 0.69$ \\
\hline $2 \mathrm{hrs}$ & $22.60 \pm 0.93^{b}$ & $38.59 \pm 0.72^{\mathrm{a}}$ & $30.5 \pm 0.69$ \\
\hline $3 \mathrm{hrs}$ & $16.12 \pm 0.84^{b}$ & $31.65 \pm 0.88^{\mathrm{a}}$ & $23.85 \pm 0.70$ \\
\hline Viability Index & $76.28 \pm 2.59^{b}$ & $121.03 \pm 1.89^{\mathrm{a}}$ & $98.56 \pm 1.89$ \\
\hline
\end{tabular}

Means in the same raw with different superscripts are significantly differ at $\mathrm{P}<0.001$ 
Table 5: ANOVA showing the effect of semen diluents, bucks individuality Freezing pograms on Pre-freeze, post-thaw semen motility and VI

\begin{tabular}{|c|c|c|c|c|c|c|c|c|c|c|c|c|c|}
\hline \multirow{3}{*}{$\begin{array}{l}\text { Source of } \\
\text { variation }\end{array}$} & \multirow{3}{*}{ df } & & & \multicolumn{10}{|c|}{ Post-thaw Semen motility } \\
\hline & & \multicolumn{2}{|c|}{$\begin{array}{l}\text { Pre-Freezing } \\
\text { Semen motility }\end{array}$} & \multicolumn{2}{|c|}{$0 \mathrm{hr}$} & \multicolumn{2}{|c|}{$1 \mathrm{hr}$} & \multicolumn{2}{|c|}{$2 \mathrm{hrs}$} & \multicolumn{2}{|c|}{$3 \mathrm{hrs}$} & \multicolumn{2}{|c|}{ Viability Index } \\
\hline & & MS & $\mathrm{F}$ & MS & $\mathrm{F}$ & MS & $\mathrm{F}$ & MS & $\mathrm{F}$ & MS & $\mathrm{F}$ & MS & $\mathrm{F}$ \\
\hline Diluents (D) & 3 & 1040.99 & $9.06^{* * *}$ & 920.12 & $6.65^{* * *}$ & 607.34 & $4.55^{* *}$ & 302.13 & $2.34^{\mathrm{NS}}$ & 1702.46 & $11.87^{* * *}$ & 1212.50 & $1.36^{\mathrm{NS}}$ \\
\hline $\begin{array}{c}\text { Bucks } \\
\text { Individualit } \\
\text { y (BI) }\end{array}$ & 21 & 412.38 & $3.59^{* * *}$ & 568.47 & $4.11^{* * *}$ & 688.27 & $5.16^{* * *}$ & 670.60 & $5.20^{* * *}$ & 538.26 & $3.75^{* * *}$ & 5429.11 & $6.10^{* * *}$ \\
\hline $\begin{array}{l}\text { Freezing } \\
\text { Regimens } \\
\text { (FR) }\end{array}$ & 1 & & & 15275.29 & $110.33^{* * *}$ & 14444.01 & $108.20^{* * *}$ & 17892.62 & $138.84^{* * *}$ & 17460.31 & $121.71^{* * *}$ & 145780.31 & $163.72^{* * *}$ \\
\hline $\mathrm{D} \times \mathrm{BI}$ & 56 & 328.103 & $2.86^{* * *}$ & 247.58 & $1.79^{* * *}$ & 256.98 & $1.93^{* * *}$ & 269.85 & $2.09^{* * *}$ & 324.86 & $2.26^{* * *}$ & 2056.17 & $2.31^{* * *}$ \\
\hline $\mathrm{D} \times \mathrm{FR}$ & 3 & & & 1112.52 & $8.04^{* * *}$ & 1002.84 & $7.51^{* * *}$ & 1217.44 & $9.45^{* * *}$ & 1066.62 & $7.44^{* * *}$ & 9554.54 & $10.73^{* * *}$ \\
\hline BI x FR & 21 & & & 188.60 & $1.36^{\mathrm{NS}}$ & 139.05 & $1.04^{\mathrm{NS}}$ & 103.48 & $0.80^{\mathrm{NS}}$ & 66.04 & $0.46^{\mathrm{NS}}$ & 765.54 & $0.86^{\mathrm{NS}}$ \\
\hline D x BI x FR & 56 & & & 93.03 & $0.67^{\mathrm{NS}}$ & 115.28 & $086^{\mathrm{NS}}$ & 84.62 & $0.66^{\mathrm{NS}}$ & 93.63 & $0.65^{\mathrm{NS}}$ & 638.34 & $0.72^{\mathrm{NS}}$ \\
\hline Error & 344 & 114.85 & & 138.45 & & 133.50 & & 128.87 & & 143.46 & & 890.44 & \\
\hline$* * \mathrm{P}<0.01$ & & & & $* * \mathrm{P}<0$ & .001 & & $\mathrm{NS}$ & n-Sign & cant & & & & \\
\hline
\end{tabular}

Table 6: Effect of semen diluents on goats reproductive performance.

\begin{tabular}{ccccc}
\hline Diluents & Fertility $\%$ & Kidding $\%$ & Fecundity \% & Prolificacy \% \\
\hline Milk & $57.76(134 / 232)^{\mathrm{a}}$ & $96.99(129 / 133)^{\mathrm{a}}$ & $179(238 / 133)^{\mathrm{a}}$ & $185(238 / 129)^{\mathrm{a}}$ \\
\hline Tris & $45.21(33 / 73)^{\mathrm{b}}$ & $90.91(30 / 33)^{\mathrm{a}}$ & $143(47 / 33)^{\mathrm{b}}$ & $157(47 / 30)^{\mathrm{a}}$ \\
\hline Na. Citrate & $34.40(215 / 625)^{\mathrm{b}}$ & $89.77(193 / 215)^{\mathrm{a}}$ & $143(307 / 215)^{\mathrm{b}}$ & $159(307 / 193)^{\mathrm{a}}$ \\
\hline Overall & $41.08(382 / 930)$ & $92.39(352 / 381)$ & $156(593 / 381)$ & $168(593 / 352)$ \\
\hline Means in the same columns with different superscripts are significantly differ at $\mathrm{P}<0.05$. &
\end{tabular}

\section{DISCUSSION}

In the present study, the pre-freeze semen motility were significant higher $(\mathrm{P}<0.05)$ in Tris $(78.49 \pm 0.96)$ than skim milk diluted semen (71.88 \pm 1.29$)$. However, the post-thaw semen motility and viability index were highly significant $(\mathrm{P}<0.05)$ for skim milk $(46.44 \pm 1.33$ and $103.48 \pm 3.38$, respectively) than other diluents. This means, under our conditions, milk extender appeared to provide higher in vitro spermatozoa viability. These findings to be in harmony with those recorded by Chehadeh et al (2001) they observed that Tris was the better diluent for maintaining goat sperm motility $(77.08 \%)$ after semen dilution than Milk (66.92\%), CEGLY diluent $(66.00 \%)$ and Sodium Citrate (64.00\%) extenders. Also, Dorado et al. (2007) detected that, TRIS extender provided more effective preservation of total motility, velocity parameters and amplitude of lateral head displacement after freezing than milk extender. However, Salvador et al. (2007) compared the effect of three extenders for buck semen conservation; skimmed Milk, sodium Citrate and Tris-based diluents on the in vitro viability of Murciano-Granadina goat spermatozoa stored at $5{ }^{\circ} \mathrm{C}$. Milk diluents provided higher in vitro viability of spermatozoa than semen diluted in Tris. Moreover, Maha-Ziada et al. (1998), Hassan 
(1990); Staish-Kumar et al. (1994) and Mohammed et al. (1998) obtained satisfactory post-thaw motility by freezing buffalo semen in milk diluent more than that in Tris or sodium citrate diluents. In addition, Dorado et al. (2007) observed, that, the percentage of acrosome intact spermatozoa was significantly higher in samples diluted with milk extender than Tris diluent, at the same time, semen doses cryopreserved in milk extender provided greater pregnancy rates after insemination compared to those in Tris extender (52.4\% vs $42.9 \%)$.

In the present study, post-thaw semen motility of milk diluent was sharply declined from $46.44 \pm 1.33$ at $0 \mathrm{hr}$. to $19.64 \pm 1.18$ at $3 \mathrm{hr}$. after thawing throughout the incubation period at $37^{\circ} \mathrm{C}$. This may be attributed to the rapid deterioration of buffering capacity of milk, to increased microbial growth and raising the acidity of the biological medium (Dhami and Sahni 1995). On the other hand, post-thaw semen motility of Tris diluent herein was slowly decreased from $38.80 \pm 1.40$ at $0 \mathrm{hr}$ to $25.12 \pm 1.43$ at $3 \mathrm{hr}$. after thawing. Salamon and Ritar (1982) considered Tris hydroxymethyl aminomethane, which is an important component of Tris diluent, is principally responsible for prolonging the preservation time by creating a buffer zone in and outside of the spermatozoa. In addition, the fructose content of the yolk Tris diluent may also help in maintaining the osmotic pressure, and providing nutrient for sperm metabolism.

Regarding to buck breeds present in this study and its effect on post-thaw semen motility and viability, irrespective to diluents and freezing protocol, the mean values of post-thaw semen motility at first, second and third hrs., after thawing, as well as, the viability index for different buck breeds showed non-significant differences. In accordance, Furstoss et al. (2009) evaluate genetic influencing characteristics of young buck semen production. They indicated that, no significant effect between buck breeds on the post-thaw semen motility However, results herein, showed a significant higher values $(\mathrm{P}<0.05)$ of post-thaw semen motility at $0 \mathrm{hr}$. were achieved by Aradi (42.27 \pm 0.91$)$ and Damascus (39.65 \pm 1.30$)$ than cross bucks breed; $1 \frac{1}{2} \mathrm{~A}^{1} / 2 \mathrm{D} \quad(38.11 \pm 1.71)$. Similarly, Karatzas et al. (1997) used Greek breed (Capra prisca) were synchronized and inseminated with bucks of Alpine, Saanen, and Damascus breeds for studying the fertility. Buck breeds used for preparing frozen-thawed semen affected the fertility level of the does. The kidding rate was lower in does inseminated with semen prepared from Damascus bucks breed than bucks of Alpine and Saanen breeds. Moreover, Perez and Mateos (1996) used a group of 19 bucks of two Spanish breeds to study the effect of photoperiod on semen. There were differences between breeds in semen characteristics, with higher semen production and better semen quality $(\mathrm{P}<0.01)$ observed in Malaguena than Verata bucks breed. Generally, the overall means of motility for post-thaw and viability index were $40.92 \pm 0.69$ and $98.56 \pm 1.89$, respectively. These results are similar with have been reported in Zaraibi (Chehadeh et al., 2001) and Cashmere bucks breed (Ritar and Ball 1993).

Spermatozoa experience physical and chemical stresses during cooling and freezing as a result of ice formation and osmotic changes in the medium. Sperm cryosurvival appears to depend on intrinsic properties of the sperm plasma membrane, such as biochemical composition, thermal behaviour, osmotic resistance and the physical stresses determined by the freezing protocol (Hammerstedt et al., 1990; De Leeuw et al., 1991). Sperm survival in such conditions can be modified by the rate at which they are cooled (Fiser and Fairfull, 1990; Bwanga et al., 1991). The effect of freezing protocols on post-thaw semen motility and viability index were indicated in this study. Irrespective to semen diluents and buck breeds, the highest mean percentages ( $\mathrm{P}$ $<0.001)$ of post-thaw motility and viability index were achieved in freezing regimen 2 than regimen 1. These findings are in agreement with Mohammed et al. (1998), recorded maximum $(\mathrm{P}<0.01)$ post-thaw motility $(63.33+1.66)$ associated with highest viability $(153.33+4.16)$ when Friesian semen was rapidly 
frozen at $2 \mathrm{~cm}$ above $\mathrm{LN}$ for $15 \mathrm{~min}$., meanwhile, the minimum motility $(16.67 \pm 6.67)$ accompanied with lower viability index $(44.17+15.45)$ were observed when relatively slow frozen at $8 \mathrm{~cm}$ above $\mathrm{LN}$ for $10 \mathrm{~min}$. Similarly, the highest $(\mathrm{P}<0.01)$ motility $(63.33 \pm 1.66)$ of post-thaw buffalo semen accompanied with highest viability index (161.67 \pm 7.12$)$ obtained when frozen at $2 \mathrm{~cm}$ above LN for $10 \mathrm{~min}$ and the lowest motility and viability were obtained when frozen at 8 $\mathrm{cm}$ above LN and maintained for $10 \mathrm{~min}$. On the basis of post-thaw motility, similarly, Bhandari et al. (1982) reported fastest timing of freezing was the best for semen survival than slow freezing, which is in similar trend to our study. Contrary, Jansen (1989) reported that fastest freezing gave low survival of sperm when fast freezing was applied (10 $\mathrm{min})$ for cattle and buffalo semen, the post-thaw motility was $47.16+1.81$ and $30.33 \pm 3.31$, respectively, and when slow freezing (15 $\mathrm{min})$ was employed post-thaw motility was $57.19 \pm 1.24$ and $34.33+3.19$, for cattle and buffalo semen, respectively. Anyhow, the cooling rates should not be too fast to cause cell death due to cold shock or too slow to cause death due to osmotic shock.

Analysis of variance showed, significant interactions $(\mathrm{P}<0.001)$ between diluents and bucks breeds on pre-freeze sperm motility, post-thaw motility and viability index. Also the interactions between freezing regimens and diluents were highly $(\mathrm{P}<0.001)$ significant on post-thaw semen motility and viability index. Our findings greatly accordance with Mohammed et al (1998), they found the interactions between freezing regimens and diluents had highly $(\mathrm{P}<0.01)$ significantly effect on viability index and AST of post-thaw buffalo spermatozoa. In opposition to our results, Dhami and Sahni (1995); Mohammed et al. (1998) found non-significant interactions between diluents and cooling rates on post-thaw bovine semen motility and viability. They ascribed this to variables which work independently of one another in the freezability and post-thaw longevity of bovine spermatozoa. Irrespective to bucks breed, the bucks individuality herein study had a significantly affect $(\mathrm{P}<0.01)$ for pre-freeze and post-thaw semen motility, as well as viability index. These results supported by study performed by Dorado et al. (2010) in which a Significant differences were found between semen extenders $(\mathrm{P}<0.001)$, bucks $(\mathrm{P}<0.05)$ and even ejaculates $(\mathrm{P}<0.05)$. Moreover, Corteel et al. (1987) observed, irrespective of the process used for freezing, differences between males regarding the freezability and fertility of semen, so they could be classified as 'good freezers' or 'bad freezers'. This variability is relatively independent of prior semen quality, and the semen of certain individuals consistently freezes with less cryoinjury than that of others. Spermatozoa acquire cold shock sensitivity as they traverse the epididymal tubules (Watson, 1981), and this is believed to be related to changes in membrane lipids during the epididymal transit. Differences in either ejaculation frequency, previously indicated by Boue and Corteel (1992), or in epididymal transit time and sperm mixing in the epididymis may provide a potential mechanism for variability in response to subsequent temperature fluctuation, explaining why ejaculates within individuals can vary in their responses to freezethawing (Watson, 1995).

The present work focused on investigating the influences of diluents used for semen extenders on the reproductive traits. In this study, although vitro evaluation of pre-freeze semen motility in skim milk was significantly lower than Na. citrate and Tris diluents, but though, the fertility and fecundity rates were significantly higher $(\mathrm{P}<0.05)$ in milk diluted semen than Tris and sodium citrate diluents. These results are in accordance with that reported by Dorado et al. (2007), where Tris-glucose and skim milk extenders were used to compare the ability of extenders to maintain sperm viability after cryopreservation. Tris extender results are better in vitro performance compared to milk, though these improvements were not reflected in fertility results, where, semen doses cryopreserved in milk extender provided greater pregnancy rates after intracervical insemination compared to those in Tris extender (52.4\% versus $42.9 \%)$. Similarly, Mara et al. (2007) used three types of diluents; skim milk (SM), TEMPOL diluent and TEMPOL+hyaluronic acid (HA) 
for goat semen dilution and consequently used as chilled semen for AI. The percentages of pregnant goats were $71.4 \%$, $61.4 \%$ and $48.8 \%$ for the three diluents, respectively. Kidding rates were $66.7 \%$, $61.4 \%$ and $48.8 \%$ for SM, TEMPOL and TEMPOL+HA, respectively without significant differences among treatment groups. In the same line, Nordstoga et al. (2010) testing the effect of two different extenders for Norwegian buck semen. Semen was diluted either in a milk-based extender containing egg yolk (M) or in Andromed (commercially extender). AI were done to 514 does during natural oestrus. Spermatozoa diluted in milk extender resulted in a 25-day non-return rate (NRR) and kidding rates of $37.3 \%$ and $24.5 \%$, respectively, while semen diluted in Andromed diluent resulted in $31.7 \%$ NRR and a kidding rate of $19.8 \%$.

Acknowledgement: The authors greatly acknowledge King Abdulaziz City for Science and Technology, Saudi Arabia, that granted this project (No.: ARP: 24-22).

\section{REFERENCES}

Amoah, E.A. and Gelaye, S. (1990): Control of reproduction in the goat, In: Gelaye, S., Amoah, E. A., Lilja, B. K. and Torando, B. (Ed.) Proc. goat production Symp. P.51. Fort Valley.

Azawi, O.I.; Al-Dahash, S.Y.A. and Juma, F.T. (1993): Effect of different diluents on Damascus goat semen. Small Ruminant Research, 9: 347-352.

Bhandari, N.; Chauhan, R.A. and Mathew, A. (1982): Note on the effect offreezing rate on the freezability of buffalo spermatozoa. Indian J. Anim. sci., 52: 1237-1238.

Boue, P. and Corteel, J.M. (1992): Aptitude of male goat sperm to withstand freezing: combined effects of season and time of sexual rest between two successive semen collections. In: Lokeshar, R.R., Editor, 1992. Recent Advances in Goat Productions. Proc. 5th Int. Conf. on Goats, New-Delhi vol. 2, pp. 1042-1045.
Bwanga, CO.; Einarsson, S. and RodríguezMartínez, H. (1991): Cryopreservation of boar semen. II: Effect of cooling rate and duration of freezing point plateau on boar semen frozen in miniand maxi-straws and plastic bags. ActaVeterinaria Scandinavica. 32(4) 455-461.

Chauhan, M.S. and Anand, S.R. (1990): Effect of egg yolk lipids on the freezing of goat semen. Theriogenology, 34: 1003.

Chehadeh, R.Y.; Maha, S. ZIiada; Ghallab, A.M. and Seida, A.A.M. (2001): Freezabelity of Zaraibi goat semen in relation to different diluents, egg yolk concentrations and glycerol level. Egyptian Soc Anim. Reprod. Fert. Thirteenth Annual Congr. Giza 22-26 January 2001.

Corteel, J.M.; Baril, G. and Leboeuf, B. (1987): Development and application of artificial insemination 4th Int. Conf. Goats. Brasilia. 1, 523-547.

De Leeuw, F.; Colenbrander, B. and Verkleij, AJ. (1991): The role membrane damage plays in cold shock and freezing injury. Reproduction in Domestic Animals Supplement. 1, 95104.

Deka, B.C. and Rao, A.R. (1987): Effect of storage at $-196 \mathrm{c}$ on quality of goat semen frozen with and wihout seminal plasma in Tris-based extender. Cherion, 16: 65. (A.B.A., vol.56, No.1487).

Dhami, A.J. and Sahni, K.L. (1995): Deepfreezing of cattle and buffalosemen with or without equilibration and its fertility trails-A comparative study. Indian j. of Anim. Sci., 65(1): 59-64.

Dorado, J.; Muñoz-Serrano, A.; Hidalgo, $M$. (2010): The effect of cryopreservation on goat semen characteristics related to sperm freezability. AnimReprod Sci. 121(1-2): 115-23.

Dorado, I. and Rodríguez, M. Hidalgo. (2007): Cryopreservation of goat spermatozoa: Comparison of two freezing extenders based on post-thaw sperm quality and fertility rates and artificial insemination. Theriogenology. 68 (2), 168-177. 
Drobnis, E.Z.; Nelson, E.A. and Burrill, M.J. (1980): Effect of survival processing variables on motility and glutamic oxaloacetic transaminase levels for frozen goat semen. III. Glycerol level. J. Anim. Sci., 51(suppl.I): 439 (abstr).

Evans, G. and Maxwell, W.M.C. (1987): Salamon's artificial insemination of sheep and goats, Butterworths. $194 \mathrm{p}$.

Fiser, P.S. and Fairfull, R.W. (1990): Combined effect of glycerol concentration and cooling velocity on motility and acrosomal integrity of boar spermatozoa frozen in $0.5 \mathrm{ml}$ straws. MolReprod Dev., 25(2): 123-9.

Furstoss, V.; David, I.; Leboeuf, B.; Guillouet, P.; Boué, P. and Bodin, L. (2009): Genetic and non-genetic parameters of several characteristics of production and semen quality in young bucks. Anim Reprod Sci., 110 (1-2): 25-36.

Hammerstedt, R.H.; Graham, J.K. and Nolan, J.P. (1990): Cryopreservation of mammalian sperm: what we ask them to survive. Journal of Andrology. 11(1), 73-88.

Hassan, H.M. (1990): Effect of certain antibiotics on some bacteria isolated from contaminated buffalo semen. M.V.Sc. Thesis. Cairo Univ.

Jansen, H.B. (1989): The influence of cooling rates practised in Netherlands on survival of bovine spermatozoa packaged in $0.25 \mathrm{ml}$ French straws. $11^{\text {th }}$ Int. Cong. On Anim. Reprod. And AI, Dublin, Ireland.

Karatzas, G.; Karagiannidis, A.; Varsakeli, S. and Brikas, P. (1997): Fertility of fresh and frozen-thawed goat semen during the nonbreeding season. Theriogenology. 15, 48(6): 1049-1059.

Leboeuf, B.; Restall, B. and Salomon, S. (2000): Production and storage of goat semen for artificial insemination. Anim. Reprod. Sci. 62, 113-141.

Maha, S. Ziada; Darwish, G.M. and Mohammed, K.M. (1998): Freezability of buffalo-semen concerning different diluents, freezing programs and thawing regimens. Alex. J. Vet. Sci., vol. 14, No. 3: 85-103.
Mara, L.; Dattena, M.; Pilichi, S.; Sanna, D.; Branca, A. and Cappai, P. (2007): Effect of different diluents on goat semen fertility. AnimReprod Sci., 102 (1-2): 152-157.

Memon, M.A.; Bretzlaff, K.N. and Ott, R.S. (1985): Effect of washing on motility and acrosome morphology of frozenthawed goat spermatozoa. Am. J. Vet. Res., 46 (2): 473-475.

Milovanov, V.K. (1962): Biology of reproduction and AI of farm animals (Tranis title) Monograph Scelkhoz Literature J Moscow.

Mohammed, KM.E.; Maha S. Ziada and Darwish, G. M. (1998): Practical trials for freezing semen ofbuffalo and friesian bulls: Effect of variousregimens of freezing, different milk extenders and types ofstraws packages on post-thawing semen characters. Assiut Vet. Med. J. 39 (77): 70-93.

Mukhrejee, T.K. and Nelson, E.A. (1987): Comparison of two diluents for freezing semen of local and F1 goats. Pertanika, 10: 113. (A.B.A., vol.57, No.325).

Nordstoga, AB.; Söderquist, L.; Adnøy, T.; Farstad, W. and Paulenz, H. (2010): Vaginal deposition of frozen-thawed semen in Norwegian Dairy goats: comparison of single and double insemination with equal total number of spermatozoa. Theriogenology. 15, 74(5): 895-900.

NRC (1981): Nutrient Requirements of Goats. National Academy Press, Washington, DC.

Perez, B. and Mateos, E. (1996): Effect of photoperiod on semen production and quality in bucks of Verata and Malaguena breeds. Small Ruminant Research, Volume 23, Issue 1, Pages 23-28.

Ritar, A.J. (1993): Control of ovulation, storage of semen, and artificial insemination of fibre-producing goats in Australia: A review. Aust. J. Exp. Agric., 33: 807-820.

Ritar, A.J. and Ball, P.D. (1993): The effect of freeze-thawing of goat and sheepsemen at a high density of spermatozoa on 
cellviability and fertility after insemination. Animal Reproduction Science, 31 (1993) 249-262 Elsevier Science Publishers B.V., Amsterdam.

Salamon, S. and Ritar, A.J. (1982): Deep freezing of Angora goat semen: effects of diluent composition, method and rate of dilution on survival of spermatozoa. Aust. J. Biol. Sci., 35: 295.

Salamon, S. and Maxwell, W.M.C. (1995): Frozen storage of ram semen. I. Processing, freezing, thawing and fertility after cervical insemination. Anim. Reprod. Sci., 37: 185.

Salvador, I.J. Yaniz; Gomez, E.A. and Silvestre, M.A. (2007): Effect of Different Extenders and Washing of Seminal Plasma on Buck Semen Storage at $5^{\circ} \mathrm{C}$. Medwell Journals, 272277.

Singh, D.K.; Singh, C.S. and Mishra, H.R. (1991): Factors affecting growth of Black Bengal and its crossbreds with Jamunapari and Beetal goats. Indian J. Anim. Sci. 61, 1101-1105.

Singh, L.P. and Purbey, L.N. (1996): Preservability of goat spermatozoa in
Tris and citrate extenders at $-196 \mathrm{C}$ and 5C. Ind. J. Anim. Sci., 66: 1139.

Sinha, S.N.; Deka, B.C.; Tamuli, M.K. and Borgohain, B.N. (1991): Effect of extenders on quality of frozen goat semen. Ind. J. Anim. Reprod., 12: 146. (A.B.A., vol.60, No.5827).

Staish-Kumar, Sahni, K.L. and Greesh Mohan (1994): Freezing of buffalo semen in different dilutors with different concentrations of glycerol and different sugars in absence of yolk. Indian J. Dairy Sci., 47, 8.

Tuli, R.K. and Holtz, W. (1992): The effect of zwitterion buffers on the freezability of boer goat semen. Theriogenology, 37: 947.

Watson, PF. (1995): Recent developments and concepts in the cryopreservation of spermatozoa and the assessment of their post-thawing function. ReprodFertil Dev. 1995, 7(4): 871-91.

Watson, P.F. (1981): The roles of lipid and protein in the protection of ram spermatozoa at $5^{\circ} \mathrm{C}$ by egg yolk lipoprotein. J. Reprod. Fertil., 62 (2) 483-492. 